\title{
From silo to cells: Reducing repetitive jobs through sociotechnical redesign
}

Vermeerbergen, Lander; Pless, Sam; Van Hootegem, Geert; Benders, Jos

\begin{abstract}
Given the negative effects of repetitiveness on employees' well-being, organisational performance, and societal expenditure, it is desirable to reduce the number of repetitive jobs. So far, intervention strategies seeking to reduce the number of repetitive jobs have mainly focused on individual jobs, without taking into consideration that these are embedded in organisational structures. Employee surveys and interviews were collected to measure changes in organisational structures and job repetitiveness in eighteen different organisations, which had each participated in a sociotechnical redesign programme. The findings show that making work units responsible for a complete product or service (i.e. implementing cells), or installing semiautonomous teams, results in a decreased number of repetitive jobs. This study underlines the impact of interventions in organisational structures on decreasing the number of repetitive jobs, and challenges current intervention strategies.
\end{abstract}

Keywords: Sociotechnical theory; repetitive jobs; organisational intervention; organisational structure 


\section{OIntroduction}

Repetitive jobs are ruining, organisational performance, and state budgets in Europe, people's lives (Hassard et al., 2014). As the number of repetitive jobs rises, so do levels of exposure to work-related psychosocial risks, as well as individual and societal costs. Between 2000 and 2015, the percentage of jobs that involved repetitive arm-hand movements grew from 57 percent to 61 percent (Eurofound, 2001, 2015). Numerous studies show the negative effects of repetitive work, resulting in increased risk for psychosocial and physical well-being and performance (Caicoya and Delclos, 2010; Devereux et al., 2004; European Agency for Safety and Health at Work, 2014; Möller et al., 2004; Vanroelen et al., 2009). Repetitive work is strenuous, mentally and physically. In 2007 alone, about 23 million people were in Europe confronted with work-related health problems (Eurostat, 2010). These hinder performance and burden social expenditure, with the annual cost to Europe of work-related depression alone estimated to be 617 billion euros (Matrix, 2013).

Intervention strategies for reducing the number of repetitive jobs in organisations are, therefore, increasingly important. Most intervention studies which aim to decrease the number of repetitive jobs in organisations mitigate physical factors in the work environment (Dempsey et al., 2010), change job content (Karasek, 1979), or increase job satisfaction by stressing valued job aspects (Locke, 1976). These intervention strategies focus on one or more 
aspects of jobs, but do not pay attention to the embeddedness of those jobs in organisations. Some studies that do take jobs' embeddedness into account (Dempsey et al., 2010; Johansson et al., 2010; Womack et al., 2009) have found that changing the organisational structure has a major impact on the number of repetitive jobs: measures such as implementing cross-functional units, teamwork, or job rotation were found to have caused large reductions in the number of repetitive jobs in organisations. However, these studies focus on just one intervention in the organisational structure rather than considering how interventions are interconnected. The Low Countries-variant of the sociotechnical systems theory (De Sitter et al., 1997; Van Eijnatten and Van der Zwaan, 1998; Van Hootegem et al., 2014; Vermeerbergen et al., 2016) poses that combinations of interventions in organisational structures are needed to substantially reduce the number of repetitive jobs. This claim prompted the current study, which sheds light on the impact of different interventions in the organisational structure on the number of repetitive jobs in organisations.

This study used the pre- and post-intervention survey data from eighteen Belgian (Flemish) organisations that participated in a workplace intervention programme using sociotechnical design principles (Van Hootegem et al., 2008). The data are analysed using crisp-set qualitative comparative analysis techniques (Joshi et al., 2015; Fiss, 2011; Rihoux and De Meur, 2009; Park, 2013; Rihoux et al., 2013; Short et al., 2008), which are highly recommended 
for investigating the combined impact of organisational interventions in small organisational samples (Rihoux and Marx, 2013; Ragin, 1987; Greckhamer et al., 2013).

\section{Objective}

This study aims to investigate the relations between different (combinations of) interventions in organisational structures and the number of repetitive jobs in organisations.

\section{Theory development and propositions}

The health risks related to job repetitiveness are intrinsically linked to the nature of the tasks that are being performed (Caicoya and Delclos, 2010; Devereux et al., 2004; European Agency for Safety and Health at Work, 2014; Möller et al., 2004; Vanroelen et al., 2009). Tasks that require short-cyclic movements, cause physical and mental distress. Yet interventions often do not target all aspects related to that repetitiveness (Dempsey et al., 2010). In general, interventions tend to be physical-centred (e.g. introducing better physical working conditions), person-centred (e.g. increasing job satisfaction), or situation-centred (e.g. introducing job enlargement) (for examples see: Hedge, 2004; Philips, 2008; Bergamasco et al., 1998; Holtermann et al., 2010; Väänänen et al., 2003; Lang et al., 2012). The way 
tasks are organised throughout an organisation remains out of scope most of the time (Dempsey et al., 2010), even though that is exactly what makes a job repetitive or not. This insight, that repetitive jobs are related to an organisation's structure, is outlined in several studies (Dempsey et al., 2010; Johansson et al., 2010; Womack et al., 2009). Among other organisational design theories, modern sociotechnical theory (De Sitter et al., 1997; Van Eijnatten and Van der Zwaan, 1998; Van Hootegem et al., 2014; Vermeerbergen et al., 2016) maintains as a key argument that jobs are embedded in the structure of an organisation. This theory developed a systematic framework to assess organisational structures and to predict their effects on indicators of working life quality, such as job repetitiveness." (De Sitter et al., 1997; De Sitter, 2000). The following sections outline this theory and derive propositions from it.

\section{Modern sociotechnical systems theory}

Sociotechnical systems theory was developed by Trist and Bamforth (1951) and Emery (1959) at the London-based Tavistock Institute. Ulbo de Sitter and his associates incorporated classic sociotechnical principles into a methodology to design organisations. Most notably, Ashby's Law of Requisite Variety (1958) forms the basis of an approach to first reduce organisational complexity as much as possible, and next design effective control mechanisms to cope with the remaining complexity (cf. Van 
Eijnatten, 1993: 58-66; Benders et al., 2000). This so-called modern sociotechnical theory (MST) aims to design organisations that perform well economically and at the same time offer meaningful jobs. Karasek's notion of 'active jobs' (1979) is incorporated in MST: job demands and job controls are balanced, and the job demands are of a sufficient level. Since repetitiveness generally implies low job demands (Van Hootegem et al., 2014), this job characteristic is not compatible with the active jobs aimed for when applying MST. Whether or not jobs are repetitive depends on how the tasks of work units are divided internally; and vice versa, a work unit's tasks result from decisions on how to divide work intra-organisationally. Thus, job design is contingent on higher-level decisions. At all levels, balancing control needs and opportunities is key, as the Law of Requisite Variety posits.

The following sections discuss this in more detail, and present the propositions derived from it.

\section{Designing work units}

Work units are created around either specific operations or particular products (or services) (Huys et al., 1999; Sels and Huys, 1999; Van Hootegem, 2000). Operations-focused departments, generally known as 'functional silos', are specialised in one or a limited number of operations. Consequently, often several departments are involved in producing a particular product, with 
semi-finished products being transported from department to department. On the contrary, products may also be taken as criteria to form departments. In this case, the different functional operations needed to make a product are grouped within a product-focused department, and products only flow within the department. This type of department is often called 'flow' or 'streamfocused'. In that case, related products are grouped and all necessary operations are placed within the cell. MST prefers cells as work units, as a structure with cells is considerably less complex than a silo structure, and can thus be managed much more easily (De Sitter et al., 1997). This management is preferably as autonomous as possible, allowing the unit to control its production locally to the fullest possible extent. In this way, the ideal task environment is created for semi-autonomous teams to function (Benders et al., 2006). Figure 1 shows a graphical depiction of each type of work unit.

\section{[INSERT FIGURE 1 ABOUT HERE]}

Having been designed, the units are to perform operational and control tasks to meet the assigned production targets. In silos, the variety of operational tasks can be high depending on the product range and variability, and product complexity (Huys et al., 1999). In general, there is an intermediate variation in operational tasks (Niepce and Molleman, 1996). The typically large 
number of products makes production hard to oversee and manage, incentivising centralised control. The net hypothesised result for jobs is that they score intermediately on repetitiveness, lacking control tasks. In cells, different types of operations are grouped and several products are made, leading to considerable variety in operational tasks (Niepce and Molleman, 1996). Furthermore, the idea is to assign control tasks to this level as much as possible (Benders et al., 2006). Both factors facilitate low repetitiveness (Sels and Huys, 1999). Table 1 is an overview of how work units impact repetitiveness.

\section{[INSERT TABLE 1 ABOUT HERE]}

\section{Job design}

So far, we have discussed the design of work units and have showed how this hypothetically impacts jobs' repetitiveness according to MST. However, there is also latitude at the level of designing jobs (De Sitter, 2000; Den Hertog, 1977). An often-mentioned measure in the literature is to implement job rotation (Conti et al., 2006; Molleman, 2000).

With this in mind, we can postulate the following four propositions (the terms 'necessary' and 'sufficient' are explained in the method section). 
Proposition 1: Changing from silos to cells is necessary or sufficient for the number of repetitive jobs to decrease.

Proposition 2: Implementing semi-autonomous teams is necessary or sufficient for the number of repetitive jobs to decrease.

Proposition 3: Implementing job rotation is necessary or sufficient for the number of repetitive jobs to decrease.

Proposition 4: Changing from silos to cells and implementing semiautonomous teams is necessary or sufficient for the number of repetitive jobs to decrease.

\section{Methods}

\section{Study design}

The study is designed as a comparative case study, which uses a quasiexperimental pretest-posttest design (Shadish et al., 2002). A comparative case study design is used to examine the impact of interventions in the organisational structure on workers' experience of job repetitiveness. Data was collected from eighteen organisations, which intervened differently in their organisational structure, before and after the intervention. The main advantage of this design is that we were able to question the same employees about their experience of repetitiveness, so that employee characteristics were held as constant as possible. Ultimately, this made it possible to examine 
whether changes in the number of repetitive jobs differed depending on the type of intervention realised within organisations.

\section{Data collection}

The studied organisations participated in the workplace innovation program 'Flanders Synergy' between 2011 and 2014 in Flanders (Belgium). Before and after the intervention, interviews were conducted and surveys were filled out. Figure 2 summarises the different steps in the data collection process. Face-to-face topic interviews were used to collect data on the interventions in organisational structures. Employee surveys were used to collect data on repetitiveness.

\section{INSERT FIGURE 2 ABOUT HERE}

The study sample included eighteen organisations and 396 employees. Five organisations were situated in the industry and fourteen were service organisations. Six organisations employed less than 50 employees, nine organisations employed between 50 and 250 employees, and three organisations employed more than 250 employees. Of the employees included in the sample, 53 percent of the employees were men; 56 percent had a college degree or higher; 19 percent were blue-collar workers; 81 percent were white collar workers. The average age was 42 , with the average 
tenure of nine years. 30 percent of the employees were working in industry, 70 percent in services. Preliminary analyses showed that the study findings were independent of which sector the organisations were in.

Related to the interventions in the organisational structures, we note that the study sample only included organisations which had silos before the intervention. 5 out of the 18 organisations in the sample implemented cells. 12 out of the 18 organisations realised semi-autonomous teams. 12 out of the 18 organisations implemented job rotation. Table A1 in the supplementary materials summarises the interventions included in the sample.

In the next sections we first discuss the manner in which we used surveys, thereafter we outline how we used interviews.

The use of surveys

We sent questionnaires to all employees in the eighteen organisations, both before and after the interventions. These questionnaires collected information on job repetitiveness. Web questionnaires were sent to all employees with an organisational e-mail account, while written questionnaires were sent to the employees without one. In addition, two reminders were sent to all employees. To ensure anonymity, sealed and stamped envelopes and central collection boxes were used, and if they desired, employees could also send their questionnaire directly to the researchers. 
The data sample consisted of 396 employees who filled out the questionnaires before and after the intervention. The response rate in 2011 was 74 percent (682 of the 924 questionnaires were filled out), while the response rate in 2014 was 62 percent (589 of the 958 surveys were filled out). The dropout rate between both measurements was 32 percent. A preliminary multivariate analysis of variance did not show significant differences in job repetitiveness between the dropouts and the respondents who answered both in 2011 and 2014. This suggests that the dropping out of employees was not selective.

Two measures of job repetitiveness were used in order to increase the reliability of the study's findings. In the findings section no difference is made between the two measures, as both led to the same findings. The first measure is cycle time and is measured by the question of Kraan et al. (2000): "How long does it take before the same task comes back?" The scale anchors were: "Less than 90 seconds", "90 seconds - 5 minutes", "5 minutes - 10 minutes" and "More than 10 minutes".

The second measure includes statements of the job content questionnaire (Karasek et al., 1998) and relates to monotony, variety of tasks and shortcycles of tasks: "My work is monotonous", "My work is varied" and "In my job the same short-cycled tasks are returning continuously". The scale anchors varied from 1 (completely agree) to 5 (completely disagree). The final construct combined these three statements (mean $=2.08$ and $\mathrm{SD}=0.78$ ). The factor loadings of each item were higher than 0.50 and therefore show a 
high construct validity. The Cronbach $\alpha$-value was 0.71 and thus showed a good internal reliability (Hair et al., 2010).

The change in repetitiveness between 2011 and 2014 was dichotomised, in line with the csQCA method (see analysis section for more information on csQCA). Following Buck and Pack (1992), jobs with a cycle time of less than 10 minutes were defined as repetitive. For the second measurement, jobs which employees scored as less than 2.51 (i.e. the middle of the scale or less) were defined as repetitive. Job repetitiveness was aggregated from the job to the organisational level for both measures, as our study interest is the evolution of the number of repetitive jobs in organisations. The final outcome was the difference in the number of repetitive jobs in organisations before and after the intervention. In the findings section we do not distinguish between both measures, as the findings for both measures are the same.

\section{The use of interviews}

Researchers and case consultants conducted interviews with the managers of the participating organisations before and after the intervention in order to in order to understand whether and how the implementation of the intervention caused change within the organisational structure. The median age of the consultants was 48 years; three out of the nine consultants were men; seven had a university degree or $\mathrm{PhD}$. All consultants were trained in sociotechnical theory and obtained a certificate in workplace innovation. In two organisations researchers conducted the interviews, in 16 organisations the 
case consultants conducted the interviews. In all of the organisations the authors conducted site visits and short interviews with the managers to test the quality of the data collected by the consultants.

The interviews were face-to-face topic interviews. The topics were based on a sociotechnical measurement instrument which was designed to assess organisational structures (Doorewaard et al., 2002; Kern and Schumann, 1987). Its use resulted in a systematic way of documenting the interventions. After each interview the interviewer (researcher or consultant) filled out a questionnaire on the organisation structure.

The implementation of cells was assessed with the question "How are the operational activities structured in the organisation?" (Van Hootegem et al., 2014). The answer categories were straightforward: (1) "Activities are grouped according to operations. Specialised groups can deliver and receive output from each other", and (2) “Activities are grouped into separate flows. These groups have their own input and output". The first category indicates a silo structure, the second a cell structure.

The implementation of semi-autonomous teams was represented by the answers to two questions on teamwork (Van Hootegem et al., 2014) and seven questions on the autonomy of these teams (Nijholt and Benders, 2010). The first teamwork question was: "Do (most of) the members of the work units have a common output resulting from joint collaboration?". The answer categories were: "Yes, most work unit members have a common output" and 
"No, most work unit members carry out their own tasks and have an individual output". The second question was "Can the outputs of the work units be considered as rounded-off, recognisable outputs?". The answer categories were: "Yes, the work units have rounded-off and recognisable outputs" and "No, the work units fulfil a number of sub-tasks, which do not result in rounded-off and recognisable outputs". Organisations that belonged to the first answer categories of both questions had implemented teams. Team autonomy was measured with seven questions about the decision authority regarding the following seven aspects of work: allocation of work; scheduling of work; quality of work; time-keeping; attendance and absence control; the coordination of work with other internal groups; and improving work processes (Nijholt and Benders, 2010). Semi-autonomous teams have realised at least four of these seven aspects.

The implementation of job rotation was operationalised by the question "Is there rotation of team members between the different task packages in the teams?" (Van Hootegem et al., 2014). The four answer categories were: "Yes, for most of the employees", "Yes, for some employees", "No, most employees are allocated to one task package but there are some polyvalent functions which rotate between most of the task packages" and "No, most employees are allocated to one task package". Organisations that were categorised under the first or the second answer were defined as organisations that had job rotation. 


\section{Data analysis}

The data was analysed using crisp-set qualitative comparative analysis (csQCA). Tosmana 1.52 was used to analyse the data. csQCA is an upcoming analysis technique which was developed by Ragin $(1987 ; 2000)$, and has since been used increasingly in the social sciences (Fiss et al., 2011; Rihoux et al., 2013; Joshi et al., 2015). The next section explains the appropriateness of the csQCA for examining the research propositions. Thereafter, the manner in which the output of the csQCA is used to confirm or reject the propositions is explained. Finally, indices are presented which show the strength of csQCA models.

$\operatorname{cs} Q C A$

csQCA is a suitable analysis method for our study objective on the (combined) impact of organisational interventions. The reason for this is that the method understands cases [cfr. organisations] as the aspects [interventions] they combine (Ragin, 1999; Rihoux, 2003). This case view makes it possible to study causal complexity (Schneider \& Wagemann, 2006), which is 'the fact that outcomes often result from several different, nonoverlapping combinations of conditions [i.e. interventions]' (Ragin, 1999). Examining causal complexity is in line with our objective to study which (combination of) interventions are needed to decrease the number of repetitive jobs in organisations. In our QCA we searched for similarities and differences across organisations by comparing combinations of interventions. 
csQCA is also a suitable analysis method for the size of our data sample. csQCA systematically compares moderate groups of 12 to 50 case organisations (Greckhamer et al., 2013), a sample size which is often overlooked by small-n in-depth qualitative as well as by large-n quantitative research (Rihoux, 2003). csQCA is therefore an adequate tool for studying similarities and differences between the 18 organisations.

csQCA: the output of the analysis and the propositions

The output of a csQCA illustrates whether an intervention is 'sufficient' or 'necessary' for a decrease in the number of repetitive jobs. Interventions are 'necessary' when present in all organisations with a decrease in the number of repetitive jobs. Interventions are 'sufficient' when present in some of the organisations which had a decrease in the number of repetitive jobs. By stating which interventions are necessary and which are sufficient, we are able to confirm or reject propositions 1,2 , and 3 .

The output of a csQCA also illustrates whether a combination of interventions is needed to decrease the number of repetitive jobs. A comparison between the theoretical combinations of interventions (in figure A1 in appendix) and the output of the analysis (in figure 3) served as an empirical assessment. By stating whether a combination of interventions is necessary or sufficient, we are able to confirm or reject proposition 4 .

csQCA: indices for evaluating the strength of csQCA models 
Two indices are commonly used to interpret the strength of the output of csQCA models (Marx, 2010; Marx \& Dusa, 2011; Ragin, 2006). The first index, 'complexity', shows whether the csQCA findings are parsimonious: the outcome is preferably explained in a simple manner. If the index scores 1 , all cases are represented by one configuration each and the output is not parsimonious. Marx (2010) argues that a score as close to 0 as possible is strived for, as the model is then able to drastically reduce complexity. The model studied here is a highly parsimonious model with a complexity score of 0.11 , which makes it an attractive model to use.

The second index, 'consistency', shows the degree to which cases agree in displaying the outcome (Ragin, 2006). Ragin (2006) argues that this index should be as close as possible to 1, which represent a perfect consistency, and cannot be lower than 0.75 . The model under investigation appears to be perfectly consistent, with a score of 1 on the consistency index.

\section{Findings}

To increase the comprehensibility of our model, we first present the separate propositions, before showing the full csQCA model (see figure 3).

Propositions 1, 2 and 3 describe the impact of individual interventions in the organisational structure on changes in the number of repetitive jobs. Firstly, proposition 1 predicted that organisations which implemented cells would 
have a decrease in the number of repetitive jobs. Table 2 illustrates that all five organisations which realised cells noted a decrease in the number of repetitive jobs. In contrast, only six organisations that did not implement cells experienced a decrease in the number of repetitive jobs. Implementing cells is thus indeed related to a lower number of repetitive jobs, but other (combinations of) interventions might also decrease the number of repetitive jobs. In other words, the implementation of cells seemed sufficient, but not necessary to decrease the number of repetitive jobs. Consequently, proposition 1 is confirmed.

\section{INSERT TABLE 2 ABOUT HERE}

Secondly, proposition 2 advanced that realising semi-autonomous teams would effectuate a decrease in the number of repetitive jobs in organisations. Table 3 shows that all seven organisations that implemented semiautonomous teams experienced a decrease in the number of repetitive jobs. Interestingly, four organisations that did not implement this intervention also displayed a decrease in the number of repetitive jobs. The organisations that decreased their number of repetitive jobs without implementing semiautonomous teams had all implemented a cell structure. The implementation 
of semi-autonomous teams is sufficient but not necessary to decrease the number of repetitive jobs. Hence, proposition 2 was also confirmed.

\section{INSERT TABLE 3 ABOUT HERE}

Thirdly, proposition 3 hypothesised that the implementation of job rotation would decrease the number of repetitive jobs. Table 4 shows that four of the nine organisations that applied job rotation showed a decrease in the number of repetitive jobs. Remarkably, seven of the nine organisations which had not applied job rotation saw a decrease in the number of repetitive jobs as well. Job rotation therefore seemed neither sufficient nor necessary to decrease the number of repetitive jobs. Consequently, proposition 3 was rejected.

INSERT TABLE 4 ABOUT HERE

Proposition 4 described the need for a combination of interventions to decrease the number of repetitive jobs. Our findings show however that a decrease in the number of repetitive jobs is not explained by combinations of 
interventions; realising just cells or semi-autonomous teams is sufficient for a decrease. However, when examining the data more in detail, it was found that the organisation which implemented cells and semi-autonomous teams had the sharpest decrease in the number of repetitive jobs (-22 percent). Consequently, proposition 4 was partly confirmed.

The findings outline two sufficient interventions, which can also be merged into a third combined intervention, through which organisations can decrease the number of repetitive jobs. We summarised these interventions as follows (see also figure 3):

- Silo organisations that implemented cells had a decrease in the number of repetitive jobs, independently of other selected interventions.

- Silo organisations that implemented semi-autonomous teams had a decrease in the number of repetitive jobs, independently of other selected interventions.

- Silo organisations that implemented cells and semi-autonomous teams had the sharpest decrease in the number of repetitive jobs, independently of other selected interventions.

Our findings thus show that these two interventions are sufficient to decrease repetitive jobs, but also interchangeable. Only silo organisations that did not implement cells or semi-autonomous teams had an increase in the number of repetitive jobs, whatever other intervention they implemented. 


\section{INSERT FIGURE 3 ABOUT HERE}

\section{Discussion and conclusion}

This study investigates whether, and which, interventions in organisational structures decrease the number of repetitive jobs in organisations. So far, intervention strategies seeking to reduce the number of repetitive jobs have mainly focused on individual jobs, without taking into consideration that these are embedded in organisational structures. MST (Modern Sociotechnical Theory) argues that active and meaningful jobs are created by reducing organisational complexity and by designing organisations so that work units have the control to deal with the remaining complexity (cf. Van Eijnatten, 1993: 58-66; Benders et al., 2000). Interventions inspired by MST should thus be able to reduce the number of repetitive jobs in organisations, as they intervene in the entire organisational structure.

Accordingly, MST (De Sitter, 1997) was used to hypothesise that (combinations of) interventions (i.e. realising cells, semi-autonomous teams, and job rotation) decrease the number of repetitive jobs in organisations with silos. The findings are that the implementation of cells or semi-autonomous teams was sufficient for a decrease in the number of repetitive jobs. Three major conclusions can be derived from the findings. 
First, the findings show that studies centred on only one intervention may be misguided. Studies have shown the impact of separate interventions on the number of repetitive jobs (e.g. Hedge, 2004; Philips, 2008; Bergamasco et al., 1998; Holtermann et al., 2010; Väänänen et al., 2003; Lang et al., 2012), but the fact that jobs are embedded within organisational structures is often overlooked (Dempsey et al., 2010). All potentially related interventions in the organisational structure need to be taken into account in order to capture the complexity that underlies organisational redesign.

Second, the results can be seen as an empirical confirmation that MST holds up as a major theory for interventions aiming to decrease the number of repetitive jobs. Cells and semi-autonomous teams are both confirmed as important interventions in this regard. Yet this study also provides an argument to amend MST. MST argues that an organisation ideally executes a combination of different compatible interventions (Vermeerbergen et al., 2016): reduce complexity and give control to the shop floor. The findings only partly confirm this hypothesis. It was indeed found that the largest decrease in repetitive jobs was in an organisation realising both cells and semi-autonomous teams. But organisations do not have to realise both cells and semi-autonomous teams to have a reduction in the number of repetitive jobs, as hypothesised by MST.

Third, this study also shows that functional silos do not necessarily lead to a low quality of working life, at least with regard to job repetitiveness. This 
assumption of MST needs to be relativised, as suggested by Dhondt \& Benders (1998). Functional silos may be associated with negative organisational consequences such as complex product flows and cumbersome coordination, but this study shows that the introduction of semi-autonomous teams helps to reduce the number of repetitive jobs, also in functional silos. Possibly, other interventions might improve other aspects of the quality of working life in functional silos as well.

Future studies might want to explore the four following possible research directions. First, other outcomes such as emotional demands, work overload, burnout, job autonomy or turn-over retention need to be investigated in a similar setting. (Combinations of) organisational interventions that do not seem to be sufficient or necessary regarding repetitiveness might be relevant in other occasions. The investigation of other outcomes might shed more light on that issue.

Second, the number of repetitive jobs increased in organisations that did not implement cells or semi-autonomous teams. This is in line with studies outlining that the percentage of repetitive jobs has been growing in Europe (Eurofound, 2001, 2015). Interventions inspired by MST might be able to stop the rise in repetitive jobs. We encourage future research explaining why despite evolving technological innovations which take over repetitive tasks an increasing number of employees works in repetitive jobs. 
Third, future research should address whether a combination of interventions in organisational structures and (physical) working condition interventions is needed. By suggesting this research direction, we specifically aim to integrate organisational redesign with other intervention strategies that might decrease the number of repetitive jobs in organisations.

Fourth, future studies might want to perform a more precise analysis of changes in repetitiveness at the group or individual level as well. We did not investigate group or individual effects with regards to the outcome because our focus primarily lies with how the organisation as a whole is affected by different interventions. Such studies will be able to examine whether MST interventions decrease repetitiveness for shop floor employees, while increasing repetitiveness for employees higher up the hierarchy. This can be expected because MST interventions aim to broaden shop floor employees' task pool, while giving them more control over their work. This often means that tasks which were previously conducted by higher echelons are moved to the shop floor. This transfer of tasks may consequently lead to less job demands and more repetitive tasks for higher echelons in organisations.

In conclusion, the findings of this study emphasise the importance of altering the organisational structure to decrease the number of repetitive jobs in organisations, and challenges current intervention strategies. 


\section{Acknowledgements}

These are submitted separately to the main text.

\section{References}

Benders J, Doorewaard H and Poutsma E (2000) Modern Socio-Technology. In: Beyerlein MM (ed) Work Teams: Past, Present and Future. Boston: Kluwer, pp. 169-180.

Benders J, Hoeken P, Batenburg R and Schouteten R (2006) First organise, then automate: a modern socio-technical view on ERP systems and teamworking. New Technology, Work and Employment 21(3): 242-251.

Bergamasco R, Girola C and Colombini D (1998) Guidelines for designing jobs featuring repetitive tasks. Ergonomics 41(9): 1364-1383.

Buck H and Pack K (1992) Arbeitsystemgestaltung in der Serienmontage: Bestandsaufnahme und Gestaltungsmöglichkeiten]. Düsseldorf: VDI-Verlag.

Caicoya M and Delclos G (2010) Work demands and musculoskeletal disorders from the Spanish National Survey. Occupational Medicine 60(6): $447-450$ 
Conti R, Angelis J, Cooper C, Faragher B and Gill C (2006) The effects of lean production on worker job stress. International Journal of Operations \& Production Management 26(9): 1013-1038.

Den Hertog J (1977) Werkstructurering. Alphen aan de Rijn\Brussels: Samson.

De Sitter L (2000) Synergetisch produceren. Human resources mobilization in de produktie: een inleiding in. Assen: Van Gorcum.

De Sitter L, Den Hertog J and Dankbaar B (1997) From complex organisations with simple jobs to simple organisations with complex jobs. Human Relations 50: 497-534.

Dempsey P, Mathiassen S, Jackson J and O'Brien N (2010) Influence of three principles of pacing on the temporal organisation of work during cyclic assembly and disassembly tasks. Ergonomics 53(11): 1347-1358.

Devereux J, Rydstedt L, Kelly V, Weston P and Buckle P (2004) The role of work stress and psychological factors in the development of musculoskeletal disorders: the stress and MSD study. Available at: 
http://www.hse.gov.uk/research/rrhtm/rr273.htm (accessed 15 December 2016).

Dhondt S and Benders J (1998) Missing links. Production structures and quality of working life in the clothing industry. International Journal of Operations \& Production Management 18(12): 1189-1204.

Doorewaard H, Van Hootegem G and Huys R (2002) Team responsibility structure and team performance. Personnel Review 31(3): 356-370.

Emery F (1959) Characteristics of socio-technical systems. London: Tavistock Institute.

European Agency for Safety and Health at Work (2014). Calculating the cost of work-related stress and psychosocial stress. A literature review. Available at: https://osha.europa.eu/en/publications/literature_reviews/calculating-thecost-of-work-related-stress-and-psychosocial-risks/view (accessed 15 December 2016).

Eurofound (2001) Third European survey on working conditions 2000. Dublin: European Working and Condition Observatory. 
Eurofound (2015) First findings: Sixth European Working Conditions Survey

- Résumé. Dublin: European Working and Condition Observatory.

Eurostat (2010) Health and safety at work in Europe (1999-2007) A statistical portrait. Luxembourg: Publications Office of the European Union.

Fiss PC (2011) Building better causal theories: A fuzzy set approach to typologies in organization research. Academy of Management Journal 54(2): 393-420.

Greckhamer T, Misangyi VF and Fiss PC (2013) The Two QCAs: From a Small-N to a Large-N Set Theoretic Approach. Configurational Theory and Methods in Organizational Research. In: Fiss PC, Cambré B, Marx A (eds) Configurational Theory and Methods in Organizational Research. Bingley: Emerald Group Publishing Limited, pp. 49-75.

Hassard J, Teoh K, Cox T, Dewe P, Cosmar M, Gründler R, Flemming D, Cosemans B and Van den Broek K (2014) Calculating the cost of workrelated stress and psychosocial risks. Luxembourg: Publications Office of the European Union. 
Hedge A (2004) Physical methods. In: Stanton N, Hedge A, Brookhuis K, Salas E and Hendrick H (eds) Handbook of Human Factors and Ergonomics Methods. Florida: CRC Press, pp. 574-552.

Holtermann A, Jørgensen M, Gram B, Christensen J, Faber A, Overgaard K, Ektor-Andersen J, Mortensen O, Sjogaard G and Søgaard K (2010) Worksite interventions for preventing physical deterioration among employees in jobgroups with high physical work demands: background, design and conceptual model. BMC Public Health 10(1): 1-12.

Huys R, Sels L, Van Hootegem G, Bundervoet J and Henderickx E (1999) Toward less division of labor? New production concepts in the automotive, chemical, clothing, and machine tool industries. Human Relations 52(1): 6793.

Johansson B, Rask K and Stenberg M (2010) Piece rates and their effects on health and safety - a literature review. Applied Ergonomics 41(4): 607-614.

Joshi A, Son J and Roh H (2015) When can women close the gap? A metaanalytic test of sex differences in performance and rewards. Academy of Management Journal 58(5): 1516-1545. 
Karasek R (1979) Job demands, job decision latitude, and mental strain: Implications for job redesign. Administrative Science Quarterly 24(2): 285308.

Karasek R, Brisson C, Kawakami N, Houtman I, Bongers P and Amick B (1998) The Job Content Questionnaire (JCQ): an instrument for internationally comparative assessments of psychosocial job characteristics. Journal of Occupational Health Psychology 3(4): 322-355.

Kern H and Schumann M (1987) Limits of the Division of Labour. New Production and Employment Concepts in West German Industry. Economic and Industrial Democracy 8(2): 151-170.

Kraan K, Dhondt S, Houtman I, Nelemans R and De Vroome E (2000) Handleiding NOVA-WEBA Een vragenlijst om arbeidsorganisatorische knelpunten op te sporen (een hernieuwde versie). Hoofddorp: TNO.

Lang J, Ochsmann E, Kraus T and Lang J (2012) Psychosocial work stressors as antecedents of musculoskeletal problems: A systematic review and metaanalysis of stability-adjusted longitudinal studies. Social Science \& Medicine 75(7): 1163-1174. 
Locke E (1976) The Nature and Causes of Job Satisfaction. In: Dunnette M. (ed) Handbook of Industrial and Organizational Psychology. Chicago: Rand MacNally College Publishing, pp. 1297-1350.

Marx A (2010). Crisp-set qualitative comparative analysis (csQCA) and model specification: Benchmarks for future csQCA applications. International Journal of Multiple Research Approaches, 4(2), 138-158.

Marx A and Dusa A (2011). Crisp-set qualitative comparative analysis (csQCA), contradictions and consistency benchmarks for model specification. Methodological Innovations Online 6(2), 103-148.

Matrix (2013) Economic analysis of workplace mental health promotion and mental disorder prevention programmes and of their potential contribution to EU health, social and economic policy objectives. Available at: (accessed 15 December 2016).

Molleman E (2000) Modalities of semi-autonomous teams-The "must", "may", "can" and "will” of local decision making. International Journal of Operations \& Production Management 20(8): 889-910. 
Möller T, Mathiassen SE, Franzon H and Kihlberg S (2004) Job enlargement and mechanical exposure variability in cyclic assembly work. Ergonomics 47(1): 19-40.

Niepce W and Molleman E (1996) Characteristics of work organization in lean production and sociotechnical systems: a case study. International Journal of Operations \& Production Management 16(2): 77-90.

Nijholt J and Benders J (2010) Measuring the prevalence of semi-autonomous teams: taking account of defining characteristics. Work Employment and Society 24(2): 375-385.

Park SH (2013) Capital openness, monetary integration, and wage-setting coordination in developed European countries. Economic and Industrial Democracy 34(4): 636-666.

Philips J (2008) The role of excess cognitive capacity in the relationship between job characteristics and cognitive task engagement. Journal of Business and Psychology 23(1-2): 11-24.

Ragin C (1987) The comparative method: Moving beyond qualitative and quantitative methods. Berkeley: University of California.

Ragin C (1999). Using qualitative comparative analysis to study causal complexity. Health Services Research 34(5 Pt 2), 1225. 
Ragin C (2000) Fuzzy-set social science. Chicago: University of Chicago Press.

Ragin C (2006). Set Relations in Social Research: Evaluating Their Consistency and Coverage. Political Analysis 14(3), 291-310.

Rihoux B (2003) Bridging the gap between the qualitative and quantitative worlds? A retrospective and prospective view on qualitative comparative analysis. Field Methods 15(4): 351-365.

Rihoux B and De Meur G (2009) Crisp-set qualitative comparative analysis (csQCA). In: Rihoux B and Ragin C (Eds) Configurational comparative methods. Qualitative comparative analysis (QCA) and related techniques. Thousand Oaks, CA: Sage, pp. 33-68.

Rihoux B, Álamos-Concha P, Bol D, Marx A and Rezsöhazy I (2013) From niche to mainstream method? A comprehensive mapping of QCA applications in journal articles from 1984 to 2011. Political Research Quarterly 66(1): 175-184. 
Rihoux B and Marx A (2013) QCA, 25 years after "The Comparative Method": mapping, challenges, and innovations-mini-symposium. Political Research Quarterly 66(1): 167-235.

Schneider CQ and Wagemann C (2006). Reducing complexity in Qualitative Comparative Analysis (QCA): Remote and proximate factors and the consolidation of democracy. European Journal of Political Research 45(5), 751-786.

Sels L and Huys R (1999) Towards a flexible future? The nature of organisational response in the clothing industry. New Technology, Work and Employment 14(2): 113-128.

Shadish WR, Cook TD and Campbell DT (2002) Experimental and QuasiExperimental Designs for Generalized Causal Inference. New York: Houghton-Mifflin.

Short JC, Payne GT and Ketchen DJ (2008) Research on organizational configurations: past accomplishments and future challenges. Journal of Management 34(6): 1053-1079. 
Trist E and Bamforth K (1951) Some social and psychological consequences of the longwall method of coal-getting. Human Relations 4(3): 3-38.

Väänänen A, Toinen-Tanner S, Kalimo R, Mutanen P, Vahtera J and Peiró J (2003) Job characteristics, physical and psychological symptoms, and social support as antecedents of sickness absence among men and women in the private industrial sector. Social Science \& Medicine 57(5): 807-824.

Van Eijnatten F (1993) The Paradigm that Changed the Work Place (Stockholm\Assen: Swedish Center for Working Life/ Van Gorcum).

Van Eijnatten F and Van der Zwaan A (1998) The Dutch IOR Approach to Organizational Design: An Alternative to Business Process Re-Engineering. Human Relations 51: 289-318.

Van Hootegem G (2000) De draaglijke traagheid van het management: tendensen in het productie- en personeelsbeleid. Leuven: Acco.

Van Hootegem G, Huys R and Maes G (2014) Meten en Veranderen. Instrumenten bij het nieuwe organiseren. Leuven: Acco. 
Van Hootegem G, Huys R, Van Beek G and Beens E (2008) In het land van Flanders Synergy. Werken en ondernemen in een innovatieve economie. Leuven: Acco.

Vanroelen C, Levecque K, Moors G, Gadeyne G and Louckx F (2009) The structuring of occupational stressors in a Post-Fordist work environment. Moving beyond traditional accounts of demand, control and support. Social Science \& Medicine 68(6): 1082-1090.

Vermeerbergen L, Van Hootegem G and Benders J (2016) Putting a band-aid on a wooden leg: A sociotechnical view on the success of decentralisation attempts to increase job autonomy. Team Performance Management 22(7/8): 383-398.

Womack SK, Armstrong TJ and Liker JK (2009) Lean job design and musculoskeletal disorder risk: A two plant comparison. Human Factors and Ergonomics in Manufacturing \& Service Industries 19(4): 279-293.

\section{Appendices}

[INSERT TABLE A1 ABOUT HERE] 
[INSERT FIGURE A1 ABOUT HERE] 
Table 1: Work unit design and the repetitiveness of jobs

\begin{tabular}{|l|l|l|}
\hline Type of work units & Silo & Cell \\
\hline Variety of operational tasks & Intermediate & Large \\
\hline Control tasks & Few & Many \\
\hline Repetitiveness & Intermediate & Low \\
\hline
\end{tabular}

Table 2. Change to cells, and the evolution of the number of repetitive jobs

\begin{tabular}{|c|c|c|c|}
\hline \multirow[t]{2}{*}{ Organisational structure } & \multicolumn{2}{|c|}{ Evolution of repetitive jobs } & \multirow{2}{*}{$\begin{array}{c}\text { Total } \\
\text { organisations }\end{array}$} \\
\hline & $\begin{array}{l}\text { Decrease in the } \\
\text { number of } \\
\text { repetitive jobs }\end{array}$ & $\begin{array}{l}\text { Increase in the } \\
\text { number of } \\
\text { repetitive jobs }\end{array}$ & \\
\hline Implementation of cells & 5 & 0 & 5 \\
\hline No change & 6 & 7 & 13 \\
\hline $\begin{array}{l}\text { Total number of } \\
\text { organisations }\end{array}$ & 11 & 7 & 18 \\
\hline
\end{tabular}

Table 3. Change to semi-autonomous teams, and the evolution of the number of repetitive jobs

\begin{tabular}{|c|c|c|c|}
\hline \multirow[t]{2}{*}{ Organisational structure } & \multicolumn{2}{|c|}{ Evolution of repetitive jobs } & \multirow{2}{*}{$\begin{array}{c}\text { Total } \\
\text { organisations }\end{array}$} \\
\hline & $\begin{array}{l}\text { Decrease in the } \\
\text { number of repetitive } \\
\text { jobs }\end{array}$ & $\begin{array}{l}\text { Increase in the } \\
\text { number of } \\
\text { repetitive jobs }\end{array}$ & \\
\hline $\begin{array}{l}\text { Implementation of semi- } \\
\text { autonomous teams }\end{array}$ & 7 & 0 & 7 \\
\hline No change & 4 & 7 & 11 \\
\hline $\begin{array}{l}\text { Total number of } \\
\text { organisations }\end{array}$ & 11 & 7 & 18 \\
\hline
\end{tabular}


Table 4. Change to job rotation, and the evolution of the number of repetitive jobs

\begin{tabular}{|c|c|c|c|}
\hline \multirow[t]{2}{*}{ Organisational structure } & \multicolumn{2}{|c|}{ Evolution of repetitive jobs } & \multirow{2}{*}{$\begin{array}{c}\text { Total } \\
\text { organisations }\end{array}$} \\
\hline & $\begin{array}{c}\text { Decrease in the number } \\
\text { of repetitive jobs }\end{array}$ & $\begin{array}{c}\text { Increase in the number } \\
\text { of repetitive jobs }\end{array}$ & \\
\hline Implementation of job rotation & 4 & 5 & 9 \\
\hline No change & 7 & 2 & 9 \\
\hline $\begin{array}{l}\text { Total number of } \\
\text { organisations }\end{array}$ & 11 & 7 & 18 \\
\hline
\end{tabular}

Figure 1: Two types of work units
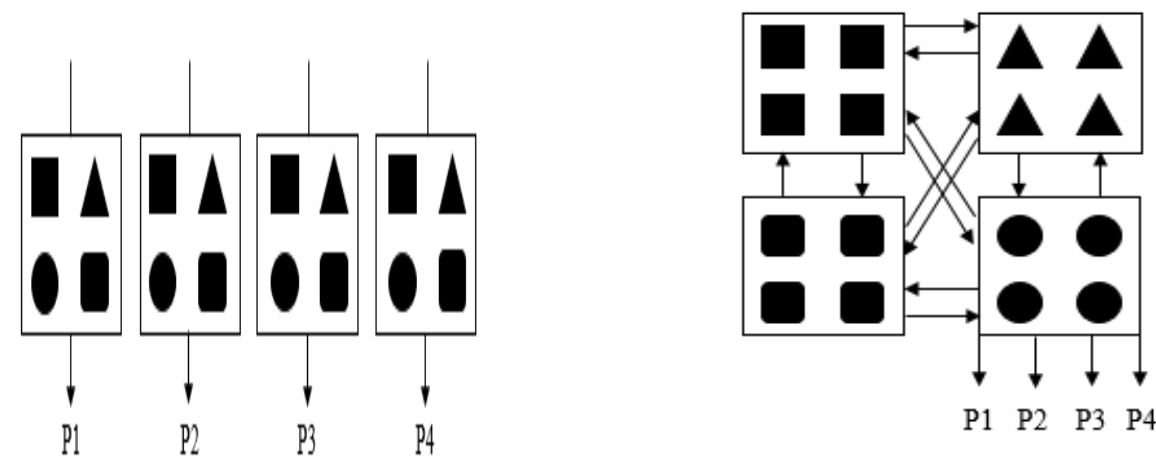

Legend: each of the four different symbols $(\square, \square, \square,($ ) refers to one set of operations; each arrow refers to one set of products, which we number product 1 $(\mathrm{P} 1)$, product $2(\mathrm{P} 2)$, product $3(\mathrm{P} 3)$ and product $4(\mathrm{P} 4)$. 
Figure 2. Timeline of data collection

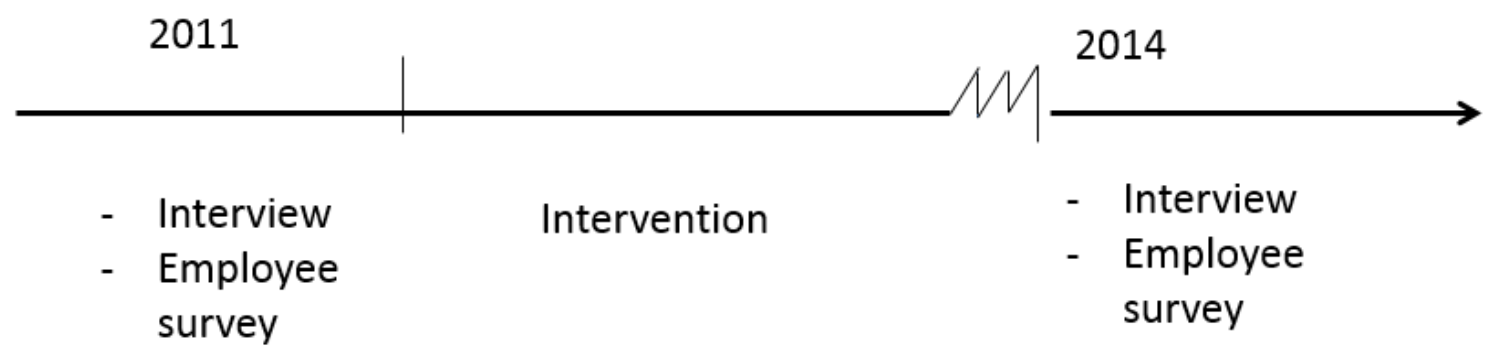

Figure 3. Empirical pathways of interventions leading to a change in the relative number of repetitive jobs

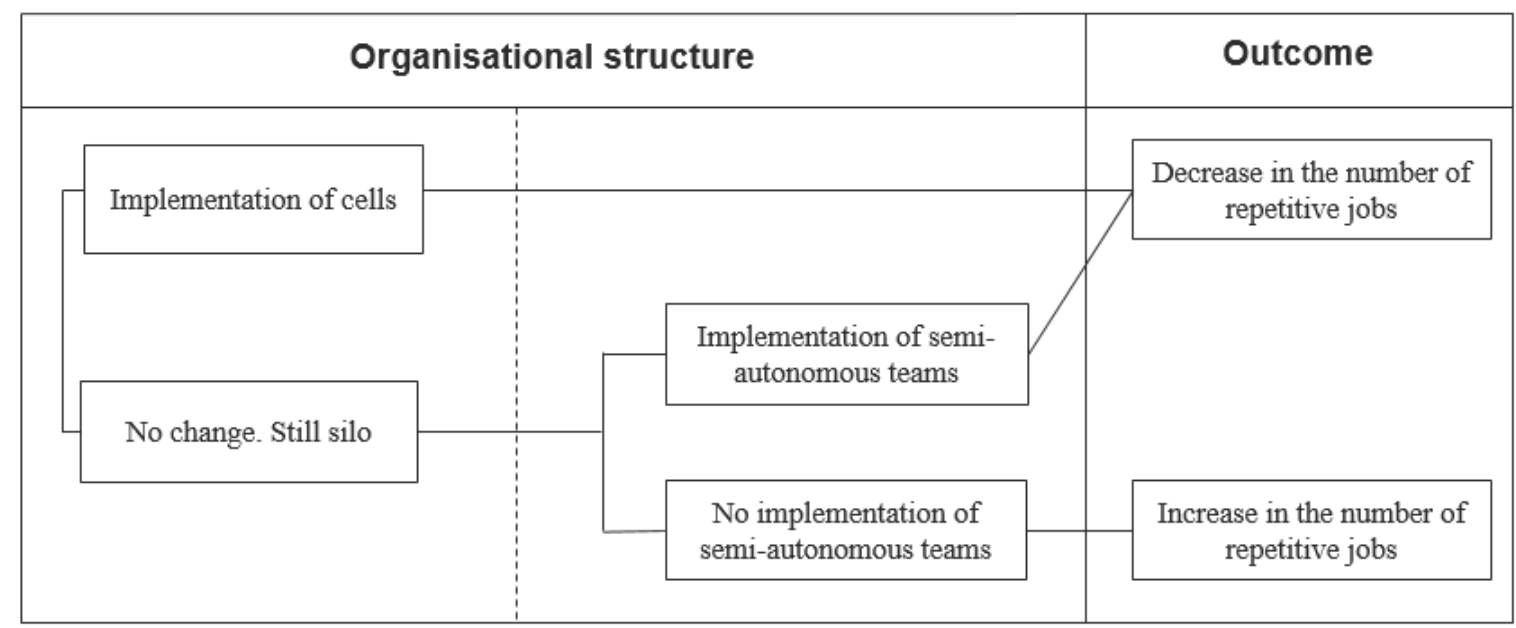


Figure A1. Theoretical patterns of interventions in organisational structures

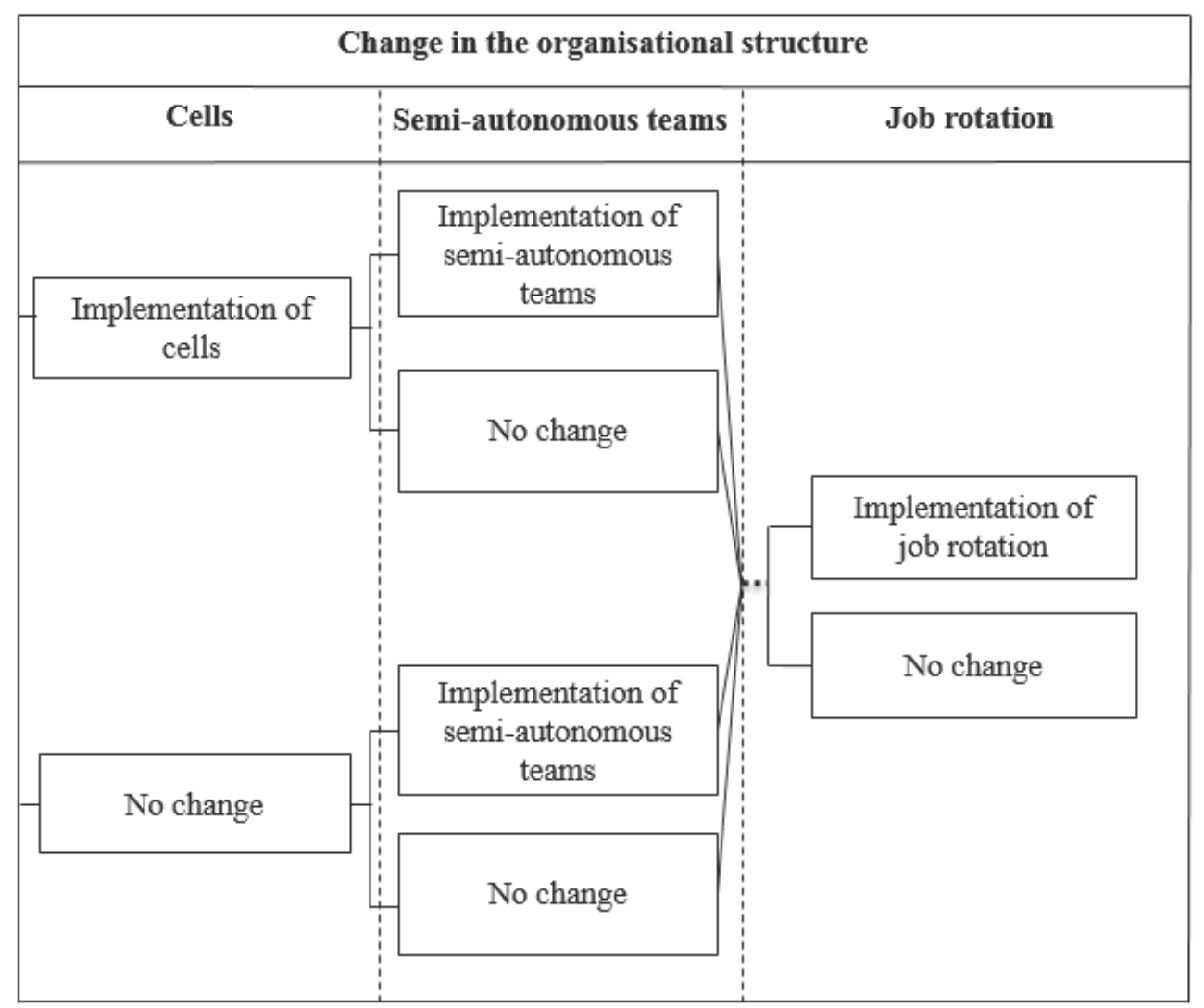


Table A1. Types of interventions and characteristics of organisation structure before the intervention

\begin{tabular}{|c|c|c|c|c|c|c|}
\hline \multirow[b]{2}{*}{ CaseID } & \multicolumn{3}{|c|}{ Interventions towards } & \multicolumn{3}{|c|}{$\begin{array}{c}\text { Organisation structure before } \\
\text { intervention }\end{array}$} \\
\hline & Cell & Job rotation & $\begin{array}{c}\text { Semi- } \\
\text { autonomous } \\
\text { teams }\end{array}$ & Cell & Job rotation & $\begin{array}{l}\text { Semi-autonomous } \\
\text { teams }\end{array}$ \\
\hline 1 & 1 & 0 & 1 & 0 & 0 & 0 \\
\hline 2 & 0 & 1 & 0 & 0 & 0 & 0 \\
\hline 3 & 1 & 0 & 0 & 0 & 0 & 0 \\
\hline 4 & 0 & 1 & 0 & 0 & 0 & 0 \\
\hline 5 & 0 & 1 & 1 & 0 & 0 & 0 \\
\hline 6 & 0 & 0 & 0 & 0 & 0 & 0 \\
\hline 7 & 0 & 1 & 0 & 0 & 0 & 1 \\
\hline 8 & 1 & 0 & 0 & 0 & 1 & 0 \\
\hline 9 & 0 & 1 & 1 & 0 & 0 & 0 \\
\hline 10 & 0 & 1 & 0 & 0 & 0 & 0 \\
\hline 11 & 0 & 0 & 1 & 0 & 0 & 0 \\
\hline 12 & 0 & 1 & 1 & 0 & 0 & 0 \\
\hline 13 & 0 & 0 & 0 & 0 & 0 & 1 \\
\hline 14 & 0 & 1 & 0 & 0 & 0 & 0 \\
\hline 15 & 1 & 0 & 0 & 0 & 0 & 0 \\
\hline 16 & 0 & 0 & 1 & 0 & 1 & 0 \\
\hline 17 & 0 & 1 & 1 & 0 & 0 & 0 \\
\hline 18 & 1 & 0 & 0 & 0 & \begin{tabular}{l|l} 
\\
\end{tabular} & 1 \\
\hline
\end{tabular}

Note: A one in the columns on the intervention defines that in these organisations the concerned intervention is implemented. A zero signifies that this

intervention was not a part of the intervention. A one in the columns on the organisation structure before the interventions indicates that before the

interventions the concerned structure characteristic was present. A zero describes that the structure characteristic was not present. 